\title{
PENGARUH AUDIT TENURE, DEBT DEFAULT, KUALITAS AUDIT DAN OPINI AUDIT TERHADAP OPINI AUDIT GOING CONCERN PADA PERUSAHAAN MANUFAKTUR YANG TERDAFTAR DI BURSA EFEK INDONESIA
}

\author{
Novita Sari \\ Yustina Triyani* \\ Program Studi Akuntansi, Institut Bisnis dan Informatika Kwik Kian Gie, \\ J1. Yos Sudarso Kav. 87, Jakarta 14350
}

\begin{abstract}
An audit opinion of going concern is an audit opinion issued by the auditor to ascertain whether a certain company can still maintain its survival for a year coming. The variables used in this research are the audit tenure, debt default, audit quality and audit opinion. These objects of research are 23 companies operate in industry sector (manufactur) which is listed in Indonesia Stock Exchange (IDX) during period 2011-2016. For hypothesis testing result show that audit tenure does not have sufficient evidence of significant effect on the audit opinion of going concern, debt default does not have sufficient evidence of significant effect on the audit opinion of going concern audit opinion of going concern, quality audit does not have sufficient evidence of significant effect on the audit opinion of going concern the audit opinion of going concernand audit opinion there is liable to audit opinion from previous year of going concern.
\end{abstract}

Keywords: Audit Opinion Of Going Concern, Audit Tenure, Debt Default, Quality Audit, And Audit Opinion From Previous Year.

\begin{abstract}
Abstrak
Opini audit going concern merupakan opini audit yang dikeluarkan oleh auditor untuk memastikan apakah perusahaan dapat mempertahankan kelangsungan hidupnya setidaknya untuk satu tahun ke depan. Variabel - variabel yang digunakan dalam penelitian ini berupa audit tenure, debt default, kualitas audit dan opini audit tahun sebelumnya. Sampel penelitian ini terdiri dari 23 perusahaan manufaktur yang terdaftar di BEI selama periode 2011-2016. Pengujian yang dilakukan adalah uji analisis statistik deskriptif, uji kesamaan koefisien dan uji regresi logistik. Hasil pengujian uji logistik menunjukkan bahwa audit tenure tidak terdapat cukup bukti terhadap penerimaan opini audit going concern, debt default tidak terdapat cukup bukti terhadap penerimaan opini audit going concern, kualitas audit tidak terdapat cukup bukti terhadap penerimaan opini audit going concern dan terdapat cukup bukti bahwa opini audit tahun sebelumnya cenderung menyebabkan penerimaan opini audit going concern.
\end{abstract}

Kata kunci: Opini Audit Going Concern, Audit Tenure, Debt Default, Kualitas Audit

\footnotetext{
* Alamat kini:Institut Bisnis dan Informatika Kwik Kian Gie, Jln Yos Sudarso Kav. 87 Sunter, Jakarta 14350 Penulis untuk Korespondensi: Telp. (021) 65307062 Ext. 708. E-mail: yustina@kwikkiangie.ac.id
} 


\section{Pendahuluan}

$\mathrm{D}$ ewasa ini pertumbuhan dan perkembangan dunia usaha melaju dengan sangat pesat. Hal ini memicu persaingan yang semakin ketat di antara pelaku bisnis. Kondisi perekonomian di Indonesia yang mengalami peningkatan menyebabkan permintaan laporan keuangan semakin meningkat. Laporan keuangan adalah media komunikasi yang digunakan perusahaan untuk memberikan informasi kepada pihak yang berkepentingan, seperti investor. Untuk membuat pemegang saham percaya terhadap laporan keuangan perusahaan. Perusahaan membuat kebijakan yaitu melakukan audit atas laporan keuangan oleh akuntan publik atau auditor independen. Akuntan publik atau auditor independen adalah auditor yang bekerja pada Kantor Akuntan Publik, yaitu sebuah perusahaan auditor independen yang bertugas untuk melakukan audit atas laporan keuangan yang diterbitkan oleh perusahaan dengan aturan dan regulasi tertentu. Hal ini bertujuan untuk meningkatkan kepercayaan para pengguna laporan keuangan terhadap kinerja suatu perusahaan. Apabila suatu perusahaan menggunakan jasa KAP dengan reputasi tinggi untuk mengaudit laporan keuangan mereka, maka tingkat kepercayaan pengguna laporan keuangan akan semakin meningkat. Sehingga opini audit yang dikeluarkan oleh auditor merupakan hal yang sangat penting bagi kelangsungan hidup suatu perusahan.

Opini audit adalah pernyataan auditor terhadap kewajaran laporan keuangan dari entitas yang telah di audit. Menurut SPAP (Standar Profesional Akuntan Publik), opini audit ada 5 macam, yaitu: pendapat wajar tanpa pengecualian, bahasa penjelasan ditambahkan dalam laporan auditor bentuk baku, pendapat wajar dengan pengecualian, pendapat tidak wajar, dan pernyataan tidak memberikan pendapat.

Opini audit going concern adalah opini audit yang dikeluarkan oleh auditor karena terdapat kesangsian besar mengenai kemampuan entitas dalam mempertahankan kelangsungan hidupnya. Bagi pemakai laporan keuangan, opini going concern merupakan kabar buruk yang keberadaannya tidak diinginkan. Berbagai masalah bisa timbul terkait dengan pemberian opini going concern pada suatu perusahaan. Menurut Venuti (2007) salah satu masalah selffulfilling prophency yang mengakibatkan auditor enggan mengungkapkan status going concern yang dikeluarkan dapat mempercepat kegagalan perusahaan yang bermasalah.

Menurut O'Reilly (2010) mengungkapkan bahwa opini audit going concern melambangkan sinyal negatif bagi kelangsungan hidup perusahaan sehingga seharusnya dapat menjadi pertimbangan dalam pengambilan keputusan bagi investor, sedangkan opini audit non going concern melambangkan sinyal positif sebagai penanda bahwa perusahaan dalam kondisi yang baik. Opini audit going concern merupakan hal yang tidak diharapkan oleh perusahaan karena dapat mengakibatkan ketidakpercayaan investor dan menurunnya harga saham perusahaan.

Beberapa faktor yang diduga dapat mempengaruhi opini audit going concern adalah kualitas audit, disclosure, audit tenure, opinion shopping, debt default dan opini audit tahun sebelumnya. Menurut Yuvisa et al (2008)audit tenure adalah lamanya hubungan antara auditor dengan klien. Lamanya hubungan auditor dengan klien dapat mengurangi independensi auditor karena menggangap klien menjadi sumber penghasilan auditor.

Debt default merupakan salah satu faktor yang berpengaruh dalam penerimaan opini audit going concern. Menurut Azizah \& Anisykurlillah (2014)debt default adalah kegagalan perusahaan dalam membayar utang pokok atau bunganya pada waktu jatuh tempo. Karena kegagalan perusahaan dalam 
membayar utangnya maka auditor dapat memberikan opini going concern.

Opini yang diberikan oleh auditor mempunyai kandungan informasi, oleh sebab itu informasi yang ada harus mencerminkan keadaan yang sesungguhnya. Informasi yang berkualitas hanya dapat diberikan oleh auditor yang berkualitas juga. Menurut DeAngelo (1981) menyatakan bahwa auditor berskala besar memiliki insentif yang lebih untuk menghindari kritikan kerusakan reputasi dibandingkan auditor skala kecil. Auditor mengeluarkan opini audit going concern pada tahun yang akan diaudit didasarkan pada penerimaan opini audit yaitu opini audit tahun sebelumnya. Peluang dalam memberikan opini going concern semakin besar jika pada tahun sebelumnya dikeluarkan opini going concern.

Penelitian ini bertujuan untuk mencari bukti empiris pengaruh audit tenure, debt default, kualitas audit dan opini audit tahun sebelumnya terhadap opini audit going concern.Beberapa kajian teori pendukung yang digunakan peneliti dalam penelitian ini antara lain:

\section{Kajian Teori}

Teori agensi merupakan hubungan keagenan sebagai suatu kontrak antara principal dan agent, dimana agent adalah pihak yang menjalankan aktivitas perusahaan, principal adalah pemegang saham suatu entitas yang memberikan mandate kepada agent untuk menjalankan aktivitas perusahaan dan menyediakan sumber daya serta fasilitas untuk aktivitas perusahaan (Jensen \& Meckling,1976). Dalam teori agensi, terdapat agency conflict yang merupakan konflik kepentingan antara principal dan agent akibat adanya sifat mementingkan diri sendiri dari masing - masing individu.

Opini audit going concern adalah opini audit yang dikeluarkan oleh auditor untuk memastikan apakah perusahaan dapat mempertahankan kelangsungan hidupnya setidaknya untuk satu tahun kedepan. Perusahaan yang memperoleh opini audit going concernmengindikasikan bahwa perusahaan tersebut memiliki masalah terkait dengan kelangsungan hidup perusahaan.

Menurut Yuvisa et al (2008)audit tenure adalah lamanya hubungan antara auditor dengan klien. Lamanya hubungan auditor dengan klien dapat mengurangi independensi auditor karena menggangap klien menjadi sumber penghasilan auditor

Perusahaan yang mengalami kesulitan keuangan akan mengalami rugi operasi dan realisasi penjualan turun. Keadaan ini akan mempengaruhi kemampuan perusahaan dalam memenuhi kewajiban pokoknya dan beban bunga pada saat jatuh tempo atau default. Menurut Azizah \& Anisykurlillah (2014)debt default didefinisikan sebagai kegagalan debitor (perusahaan) untuk membayar hutang pokok dan bunganya pada waktu jatuh tempo.

Audit yang berkualitas adalah audit yang dilaksanakan oleh orang yang kompeten dan orang yang independen. Auditor yang kompeten adalah auditor yang memiliki kemampuan teknologi, memahami dan menggunakan metode penyampelan yang benar. Auditor yang independen adalah auditor yang jika menemukan pelanggaran, akan secara independen melaporkan pelanggaran tersebut.

Menurut Setyarno et al (2006) opini audit tahun sebelumnya adalah opini audit yang diterima auditee pada tahun sebelumnya. Opini audit going concern tahun sebelumnya menjadi salah satu pertimbangan auditor dalam memberikan opini audit going concern pada tahun berjalan. Apabila pada tahun sebelumnya auditor telah menerbitkan opini audit going concern, semakin besar kemungkinan auditor untuk menerbitkan kembali opini audit going concern pada tahun berikutnya jika kondisi perusahaan tidak 
mengalami perubahan atau perbaikan dari tahun sebelumnya.

\section{Pengaruh audit tenure terhadap opini audit going concern}

Adanya hubungan antara auditor dan klien dalam jangka waktu yang lama dikhawatirkan akan menimbulkan hilangnya independensi auditor. Hilangnya independensi dapat dilihat dari semakin sulitnya auditor untuk memberikan opini audit going concern.

Ha1: Audit Tenure yang pendek cenderung menyebabkan penerimaan Opini Audit Going Concern.

\section{Pengaruh debt default terhadap opini audit going concern}

Ketika suatu perusahaan memiliki hutang yang tinggi, maka kas yang ada di perusahaan akan diarahkan untuk menutup hutang yang dimiliki perusahaan yang dampaknya akan mengganggu kegiatan operasional perusahaan, dan saat perusahaan kesulitan untuk memenuhi hutangnya, auditor akan memberikan status default untuk perusahaan tersebut. Auditor dalam memberikan opini going concern akan mempertimbangkan status default.

Ha2: Debt Default yang besar cenderung menyebabkan penerimaan Opini Audit Going Concern.

\section{Pengaruh kualitas auditterhadap opini audit going concern}

KAP yang termasuk dalam big four merupakan KAP besar yang memiliki kualitas lebih baik dalam pelatihan dan pengakuan internasional. KAP besar akan cenderung lebih berani dalam mengungkapkan adanya keraguan dalam kelangsungan hidup perusahaan dan akan mengeluarkan opini going concern jika memang terbukti ada masalah pada perusahaan yang diaudit. Auditor yang memiliki reputasi dan nama besar dapat menyediakan kualitas audit yang lebih baik, termasuk dalam mengungkapkan masalah going concern.

Ha3: Kualitas Audit yang tinggi cenderung menyebabkan penerimaan Opini Audit Going Concern.

Pengaruh opini audit $^{\text {tahun }}$
sebelumnyaterhadap opini audit
concern

Auditee yang sebelumnya menerima opini going concern masih harus melalui krisis yang melanda dan secara tidak langsung, berarti perusahaan masih dalam kondisi yang kurang stabil pada periode berjalan. Auditor akan menganggap kecil kemungkinan bagi perusahaan untuk dapat pulih dalam waktu singkat, mengingat masalah yang dihadapi perusahaan cukup besar hingga sampai mengancam eksistensi perusahaan.

Ha4: Semakin sering perusahaan menerima Opini Audit Going Concern Tahun Sebelumnya cenderung menyebabkan penerimaan Opini Audit Going Concern.

\section{Metode Penelitian}

Obyek dalam penelitian ini adalah perusahaan manufakur yang sudah go public. Peneliti memilih perusahaan manufaktur karena perusahaan manufaktur merupakan jenis perusahaan yang paling banyak terdaftar di Bursa Efek Indonesia (BEI), sehingga variasi data yang ada akan semakin banyak. Perusahaan manufaktur ini memiliki transaksi yang besar, lebih kompleks dan lebih bervariasi dibanding sektor lain. Dengan memilih tahun 2011-2016 peneliti ingin menggali lebih dalam kecenderung pemberian opini audit going concern dalam rentang waktu yang cukup panjang.

\section{Variabel Penelitian}

\section{Opini Audit Going Concern}

Variabel ini diukur dengan menggunakan variabel dummy. Opini audit 
going concern diberi kode "1" dan Opini audit non going concern akan diberi kode "0".

\section{Audit Tenure}

Audit Tenure dapat didefinisikan sebagai lamanya perikatan antara KAP dengan perusahaan klien. Tahun pertama perikatan dimulai dengan angka 1 dan ditambah dengan satu untuk tahun berikutnya. Jika ada perubahan afiliasi, maka perhitungan audit tenure akan dimulai dari awal. Perhitungan dihitung dari tahun 2011 sampai 2016. (Krissindiastuti \& Rasmini, 2016)

\section{Debt Default}

Debt default diukur dengan nilai ekuitas dalam bagian ekuitas. Variabel ini menggunakan variabel dummy, "1" jika nilai ekuitasnya negatifdan "0" jika nilai ekuitasnya positif. (Retno Astuti, 2012)

\section{Kualitas Audit}

Kualitas audit diproksikan dengan menggunakan skala Kantor Akuntan Publik. Variabel ini merupakan variabel dummy dengan nilai "1" untuk Kantor Akuntan Publik yang termasuk dalam kelompok Big Four dan nilai "0" untuk Kantor Akuntan Publik yang tidak termasuk dalam kelompok Big Four. (Craswell et al, 1995)

\section{Opini Audit Tahun Sebelumnya}

Opini audit tahun sebelumnya diukur dengan opini yang diberikan oleh auditor independen terhadap laporan keuangan pada periode sebelumnya. Variabel ini menggunakan variabel dummy, "1" jika opini audit tahun sebelumnya adalah opini going concern dan " 0 " jika opini bukan going concern.

\section{Teknik Pengumpulan Data}

Teknik pengumpulan data yang digunakan dalam penelitian ini adalah teknik observasi atau pengamatan, dimana peneliti melakukan pengamatan terhadap data sekunder yang diambil dari laporan tahunan perusahaan manufaktur yang terdaftar di Bursa Efek Indonesia (BEI) periode 20112016 untuk mendapatkan data-data yang dibutuhkan atau mendukung penelitian ini yakni lamanya hubungan kerja KAP dengan klien, kegagalan perusahaan membayar hutangnya, KAP yang mengaudit laporan keuangan, dan opini audit yang diterima perusahaan tahun sebelumnya. Laporan tahunan perusahaan ini dapat diambil dari website Bursa Efek Indonesia (BEI) yaitu www.idx.co.id.

\section{Teknik Pengambilan Sampel}

Populasi dari penelitian ini adalah perusahaan manufaktur yang terdaftar di Bursa Efek Indonesia. Sampel dari penelitian ini adalah perusahaan manufaktur yang memenuhi kriteria akan disebutkan. Teknik pengambilan sampel yang akan digunakan adalah teknik Non-Probability Sampling dengan menggunakan metode Purposive Sampling. (Cooper \&Donald,2017). Kriteria yang dipertimbangkan dalam pengambilan sampel penelitian ini adalah sebagai berikut:

1. Perusahaan yang diteliti adalah perusahaan manufaktur yang terdaftar dalam Bursa Efek Indonesia.

2. Perusahaan yang menyajikan laporan keuangan yang lengkap selama periode 2011-2016.

3. Perusahaan tidak delisting selama periode penelitian.

4. Perusahaan yang memiliki tahun tutup buku pada tanggal 31 Desember.

5. Laporan keuangan menggunakan mata uang Rupiah.

6. Perusahaan yang mengalami laba negatif sekurang-kurangnya 2 periode berturutturut selama periode 2011-2016 karena pada perusahaan yang mengalami laba positif, kemungkinan penerimaan opini audit going concern menjadi lebih kecil 


\section{Teknik Analisis Data}

Teknik analisis data yang digunakan dalam penelitian ini adalah:

1. Statistik Deskriptif

Analisis statistik deskriptif digunakan untuk memberikan gambaran dan deskripsi mengenai variabel-variabel yang ada dalam penelitian. Analisis statistik deskriptif dilihat dari nilai ratarata (mean), standar deviasi, varian, maksimum, minimum, sum, range, kurtosis dan skewness (kemencengan distribusi). (Ghozali, 2016:19).

2. Uji Kesamaan Koefisien

Sebelum menjawab pengaruh variabel independen terhadap variabel dependen, kita harus mengetahui terlebih dahulu apakah data penelitian yang ada dapat dipool atau tidak melalui suatu pengujian. Pengujian ini dilakukan untuk mengetahui apakah terdapat perbedaan intercept, slope, atau keduanya di antara persamaan regresi yang ada. Bila terbukti terdapat perbedaan intercept, slope, atau keduanya di antara persamaan regresi, maka data penelitian tidak dapat di-pool, melainkan harus diteliti secara crosssectional. Tapi sebaliknya, jika tidak terdapat perbedaan intercept, slope, atau keduanya di antara persamaan regresi, pooling data penelitian dapat dilakukan. Uji kesamaan koefisien dilakukan dengan menggunakan variabel dummy. Dalam penelitian ini mengambil periode 20112016. Bila signifikansi dummy tersebut diatas nilai $\alpha=5 \%$ maka data penelitian selama 6 tahun dapat diuji secara bersama-sama (di-pool).

3. Uji Regresi Logistik

Untuk melakukan uji regresi logistik atas penelitian ini, maka peneliti melakukan overall model fit, koefisien determinasi, menilai kelayakan model regresi, matriks klasifikasi, dan estimasi parameter dan interprestasi

\section{Hasil Dan Pembahasan}

\section{Uji Statistik Deskriptif}

Berdasarkan lampiran 1, diketahui bahwa jumlah sampel penelitian untuk masing-masing variabel adalah 138 sampel. GCO merupakan variabel dummy yang memiliki nilai minimum 0 dan nilai maximum 1. Rata-rata variabel opini audit going concern 0,1594 yang berarti $15,94 \%$ dari seluruh perusahaan sampel mendapatkan opini audit going concern, dan standar deviasi sebesar 0,36740.Variabel audit tenure (AT) memiliki nilai minimum 1 dan nilai maximum 5. Rata-rata variabel audit tenure 2,1304 yang menunjukkan bahwa rata-rata hubungan perikatan auditor dengan klien dalam penelitian ini adalah 2,1304 tahun, dan standar deviasi sebesar 1,05903. Variabel debt default (DD)merupakan variabel dummy yang memiliki nilai minimum 0 dan nilai maximum 1. Rata-rata variabel debt default 0,1449 yang menunjukkan bahwa $14,49 \%$ dari sampel mengalami debt default, dan standar deviasi sebesar 0,35331. Variabel kualitas audit (KA) diproksikan dengan perusahaan yang menggunakan jasa auditor yang tergabung dalam big four. Nilai minimum 0 dan nilai maximum 1 dengan rata-rata sebesar 0,1812 yang menunjukkan bahwa $18,12 \%$ perusahaan menggunakan KAP big four dan standar deviasi sebesar 0,38655. Variabel opini audit tahun sebelumnya (LastOpn) merupakan variabel dummy yang memiliki nilai minimum 0 dan nilai maximum 1. Rata-rata variabel opini audit tahun sebelumnya 0,1377 yang menunjukkan bahwa $13,77 \%$ perusahaan menerima opini audit going concern ditahun sebelumnya dan standar deviasi sebesar 0,34582 .

\section{Uji Kesamaan Koefisien (pooling)}

Dari lampiran 2, nilai sig > 0,05 sehingga dapat disimpulkan bahwa tidak terdapat perbedaan koefisien dan data lolos uji pooling.Dengan demikian maka data dalam 
penelitian ini bisa diuji dalam satu kali pengujian (pooling).

\section{Uji Regresi Logistik}

\section{Menilai Keseluruhan Model (Overall Model Fit)}

Pengujian

kesesuaian

keseluruhan model (overall model fit) dilakukan dengan membandingkan nilai antara -2 Log Likelihood (-2LL) pada awal (Block Number $=0)$ dengan nilai -2 Log Likelihood (-2LL) pada akhir (Block Number $=1)$. Dapat dilihat dari lampiran 3bahwa nilai (-2LL) awal adalah 121,083. Setelah dimasukkan keempat variabel independen, maka nilai (-2LL) akhir mengalami penurunan menjadi sebesar 60,088. Penurunan nilai (-2LL) ini menunjukkan model regresi yang lebih baik atau dengan kata lain model yang dihipotesiskan fit dengan data, yang berarti tidak tolak Ho.

2. Koefisien Determinasi (Nagelkerke $R$ Square)

Besarnya nilai koefisien determinasi pada persamaan regresi logistik ditunjukkan oleh nilai Nagelkerke $R$ Square. Dari lampiran 4 dapat dilihat bahwa nilai Nagelkerke $R$ Square yang dihasilkan adalah sebesar 0,612 yang berarti variabel dependen dapat dijelaskan oleh variabel independen sebesar $61,2 \%$ sedangkan sisanya sebesar 38,8\% dijelaskan oleh variabel-variabel lain di luar model penelitian

\section{Menilai Kelayakan Model Regresi}

Menilai kelayakan dari model regresi dapat dilakukan dengan memperhatikan goodness of fit model yang diukur dengan Chi-Square pada kolom Hosmer and Lemeshow's. Dari lampiran 5 menunjukkan hasil pengujian Hosmer and Lemeshow's Test. Berdasarkan lampiran 5, dapat diketahui bahwa nilai signifikansi adalah 0,934 .
Nilai signifikan yang diperoleh diatas 0,05 yang berarti hipotesis nol (Ho) tidak dapat ditolak (diterima). Hal ini berarti model mampu memprediksi nilai observasinya atau model dapat diterima karena cocok dengan data observasinya sehingga model ini dapat digunakan untuk analisis selanjutnya.

\section{Matriks Klasifikasi}

Dari lampiran 6 menunjukkan bawa kekuatan prediksi dari model regresi untuk memprediksi kemungkinan perusahaan menerima opini audit going concern adalah sebesar $72,7 \%$. Hal ini menunjukkan bahwa dengan menggunakan model regresi yang digunakan, terdapat sebanyak 16 perusahaan yang diberi opini audit going concern dari 22 perusahaan yang menerima opini audit going concern. Kekuatan prediksi dari model regresi untuk memprediksi kemungkinan perusahaan menerima opini audit non going concern adalah 97,4\%, yang berarti terdapat 113 perusahaan yang diprediksi menerima opini audit non going concern dari total 116 perusahaan yang menerima opini audit non going concern.

5. Estimasi Parameter dan Interprestasinya (Uji t)

a. Audit Tenure

Pada lampiran 7 menunjukkan bahwa $\beta 1=0,129$. Nilai signifikansi AT sebesar $0,715 / 2=0,3575>\alpha(0,05)$. Artinya secara statistik audit tenure tidak cukup bukti berpengaruh terhadap penerimaan opini audit going concern.

b. Debt Default

Pada lampiran 7 menunjukkan bahwa $\beta 2=0,968$. Nilai signifikansi DD sebesar $0,216 / 2=0,108>\alpha(0,05)$. Artinya secara statistik debt default tidak cukup bukti berpengaruh terhadap penerimaan opini audit going concern. 


\section{c. Kualitas Audit}

Pada lampiran 7 menunjukkan bahwa $\beta 3=-18.563$. Nilai signifikansi KA sebesar $0,998 / 2=0,499>\alpha(0,05)$. Artinya secara statistik kualitas audit tidak cukup bukti berpengaruh terhadap penerimaan opini audit going concern.

\section{d. Opini Audit}

Pada lampiran 7 menunjukkan bahwa $\beta 4=4,056$. Nilai signifikansi LastOpn sebesar $0,000<\alpha(0,05)$. Artinya secara statistik opini audit tahun sebelumnya cukup bukti berpengaruh terhadap penerimaan opini audit going concern.

\section{Pembahasan}

\section{Pengaruh Audit Tenure Terdapat Opini Audit Going Concern.}

Berdasarkan hasil pengujian menunjukkan bahwa audit tenure tidak terbukti memiliki pengaruh dalam pemberian opini audit going concern. Dari kerangka pemikiran menyatakan bahwa manajer pasti mengharapkan hubungan antara perusahaan dengan auditor berlangsung lama karena sudah merasa nyaman dan pengetahuan auditor terhadap perusahaan tersebut sudah semakin tinggi, sehingga hubungan yang lama tersebut dapat menciptakan insentif ekonomi bagi auditor sehingga menjadi kurang mandiri. Adanya hubungan antara auditor dan klien dalam jangka waktu yang lama dikhawatirkan akan menimbulkan hilangnya independensi auditor. Hilangnya independensi dapat dilihat dari semakin sulitnya auditor untuk memberikan opini audit going concern.

Tetapi dari hasil pengujian yang telah dilakukan menyatakan bahwa lamanya hubungan perusahaan dengan auditor tidak berpengaruh terhadap penerimaan opini audit going concern dikarenakan auditor memiliki kode etik dan tidak ingin kehilangan profesionalismenya sehingga tidak menimbulkan hilangnya independensi auditor. Jadi perusahaan yang diragukan kemampuannya untuk mempertahankan kelangsungan usahanya akan tetap di berikan opini audit going concern tanpa memperdulikan lamanya perikatan. Hasil penelitian ini sejalan dengan Dewayanto (2011) yang menyatakan bahwa audit tenure tidak berpengaruh terhadap penerimaan opini audit going concern.

\section{Pengaruh Debt Default Terhadap Opini Audit Going Concern.}

Berdasarkan hasil pengujian menunjukkan bahwa debt default tidak terbukti memiliki pengaruh dalam pemberian opini audit going concern. Dari kerangka pemikiran menyatakan bahwa hal pertama yang akan dilakukan auditor untuk mengetahui kondisi kesehatan perusahaan adalah dengan memeriksa hutang perusahaan. Jika perusahaan terlambat atau tidak dapat membayar utangnya saat jatuh tempo auditor akan memberikan status default. Auditor dalam memberikan opini going concern akan mempertimbangkan status default.

Tetapi hasil pengujian menyatakan bahwa status debt default belum tentu mendapatkan opini going concern. Auditor memberikan status going concern tidak berdasarkan kegagalan perusahaan untuk membayar hutang pokok atau bunganya pada saat jatuh tempo, akan tetapi lebih cenderung melihat kondisi keuangan perusahaan secara keseluruhan. Sebagai contoh PT. Primarindo Asia Infrastructure Tbk mendapatkan status default tetapi tidak mendapatkan status opini going concern, dikarenakan kondisi keuangan secara keseluruhan PT. Primarindo Asia Infrastructure Tbk masih baik. Hasil penelitian ini sejalan dengan Susanto (2009) yang menyatakan bahwa debt 
default tidak berpengaruh terhadap penerimaan opini audit going concern.

\section{Pengaruh Kualitas Audit Terhadap Opini Audit Going Concern.}

Berdasarkan hasil pengujian menunjukkan bahwa kualiats audittidak terbukti memiliki pengaruh dalam pemberian opini audit going concern. Dari kerangka pemikiran menyatakan bahwa manusia itu selalu self interest maka kehadiran pihak ketiga yang independen sebagai mediator pada hubungan antara principal dengan agent sangat diperlukan, dalam hal ini auditor independen dipercaya bisa menjadi pihak ketiga yang menjadi penengah antara kepentingan principal dan agent. Investor akan cenderung yakin pada data akuntansi yang dihasilkan dari kualitas audit yang tinggi.

KAP yang termasuk dalam big four merupakan KAP yang memiliki kualitas audit lebih baik dalam pelatihan menjadi auditor. KAP big four akan cenderung lebih berani mengeluarkan opini audit going concern jika adanya keraguan bahwa perusahaan dapat melanjutkan usahanya.

Tetapi dari hasil pengujian yang telah dilakukan menyatakan bahwa kualitas audit yang tinggi atau rendah tidak membedakan suatu perusahaan dalam mendapatkan opini audit going concern jika auditor merasa perusahaan tidak bisa mempertahankan kelangsungan hidup usahanya, perusahaan tersebut akan menerima opini audit going concern. Penelitian ini tidak berhasil membuktikan bahwa kualitas auditberpengaruh terhadap penerimaan opini audit going concern. Hasil penelitian ini sejalan dengan Dewayanto (2011) yang menyatakan bahwa kualitas audit tidak berpengaruh terhadap penerimaan opini audit going concern.

\section{Pengaruh Opini Audit Terhadap Opini Audit Going Concern.}

Berdasarkan hasil pengujian menunjukkan bahwa opini audit tahun sebelumnya terbukti memiliki pengaruh dalam pemberian opini audit going concern. Dari kerangka pemikiran menyatakan bahwa auditor akan menganggap kecil kemungkinan bagi perusahaan yang mendapatkan opini going concern pada tahun sebelumnya dapat pulih dalam waktu singkat, mengingat masalah yang dihadapi perusahaan cukup besar hingga sampai mengancam eksistensi perusahaan. Pemikiran inilah yang membuat auditor cenderung memberikan opini yang sama atau tidak jauh berbeda dari opini audit tahun sebelumnya.

Hasil pengujian juga menyatakan bahwa opini audit going concern tahun sebelumnya yang diterima perusahaan dapat digunakan auditor sebagai pertimbangan untuk mengeluarkan opini audit yang sama pada tahun berikutnya. Hasil penelitian ini didukung oleh Dewayanto (2011) yang menyatakan bahwa opini audit tahun sebelumnya memiliki pengaruh positif terhadap penerimaan opini audit going concern.

\section{Simpulan Dan Saran}

Simpulan dari penelitian ini adalah tidak terdapat cukup bukti bahwa audit tenure, debt default dan kualitas audit cenderung menyebabkan penerimaan opini audit going concern. Akan tetapi, terdapat cukup bukti bahwa opini audit tahun sebelumnya cenderung menyebabkan penerimaan opini audit going concern.

Ada beberapa saran yang diajukan kepada peneliti selanjutnya ataupun bagi pihak yang bersangkutan adalah (1) hasil penelitian menunjukkan variabel audit tenure, debt default, kualitas audit tidak berpengaruh terhadap opini audit going concern. Maka 
untuk peneliti selanjutnya dapat menggunakan proksi yang berbeda untuk audit tenure dapat menggunakan proksi dummy diharapkan dengan proksi yang berbeda dapat memiliki hasil penelitian berbeda. (2) Untuk penelitian selanjutnya, peneliti menyarankan untuk menambah variabel independen lainnya yang berhubungan dengan opini audit going concern, seperti pertumbuhan perusahaan, ukuran perusahaan, struktur modal dan faktorfaktor lainnya. (3) Penelitian ini hanya dilakukan terhadap perusahaan sektor manufaktur yang terdaftar di Bursa Efek Indonesia, untuk peneliti selanjutnya dapat melakukan penelitian dengan obyek yang berbeda untuk memperluas sampel penelitian, seperti pada perusahaan sektor sumber daya alam dan sektor jasa.

\section{Daftar Pustaka}

Azizah, R., \& Anisykurlillah, I. 2014 ,Pengaruh Ukuran Perusahaan, Debt Default, dan Kondisi Keuangan Perusahaan Terhadap Penerimaan Opini Audit Going Concern.Accounting Analysis Journal, Vol3, No : 361-369.

Cooper, Donald R., P. S. S. 2017, Metode Penelitian Bisnis (12th ed.). Jakarta: Salemba Empat.

Craswell, A. T., Francis, J. R., \& Taylor, S. L. 1995, Auditor brand name reputations and industry specializations. Journal of Accounting and Economics, Vol 20, No $3: 297-322$.

DeAngelo, L. E. 1981,Auditor size and audit quality.Journal of Accounting and Economics, Vol 3, No 3 : 183-199.

Dewayanto, T. 2011,Analisis Faktor-Faktor yang Mempengaruhi Penerimaan Opini Audit Going Concern pada Perusahaan Manufaktur yang Terdaftar Di Bursa Efek Indonesia. Jurnal Fokus Ekonomi Vol 6, No.1 : 81-104.
Ghozali, I. 2016,Aplikasi Analisis Multivariate dengan Program IBM SPSS 23. Universitas Diponegoro.

Ikatan Akutansi Indonesia, SA Seksi508. 2001,Laporan Auditor atas Laporan Keuangan Auditan, No.29 : 1-23.

Jensen, M. C., \& Meckling, W. H. 1976,Theory of the firm: Managerial behavior, agency costs and ownership structure.Journal of Financial Economics Vol 3, No.4 : 305-360.

Krissindiastuti, M., \& Rasmini, N. K. 2016,Faktor-Faktor Yang Mempengaruhi Opini Audit Going Concern.E-Jurnal Akuntansi Universitas Udayana Vol 14, No : 451-481.

O'Reilly, D. M. 2010, Do investors perceive the going-concern opinion as useful for pricing stocks?Managerial Auditing Journal Vol 25, No : 4-16.

Pernyataan Standar Akuntansi, 220. Independensi, No.4 : 1-2.

Retno Astuti, I. 2012,Pengaruh Faktor Keuangan Dan Non Keuangan Terhadap Penerimaan Opini Audit Going Concern.Diponegoro Journal of Accounting Vol 1, No.2 : 1-10.

Setyarno, E. B., \& Januarti, I. 2006, Pengaruh Kualitas Audit, Kondisi Keuangan Perusahaan, Opini Audit Tahun Sebelumnya, Pertumbuhan Perusahaan Terhadap Opini Audit Going Concern. Pengaruh Kualitas Audit, Kondisi Keuangan Perusahaan, Opini Audit Tahun Sebelumnya, Pertumbuhan Perusahaan Terhadap Opini Audit Going Concern, No : 23-26.

Susanto, Y. K. 2009, Faktor-Faktor Yang Mempengaruhi Penerimaan Opini Audit Going Concern.Simposium Nasional Akuntansi X Vol 11, No.3 : 1-26. 
Venuti, B. E. K. 2007, The Going Concern Assumption Revisited: Assessing a Company's Future Viability, No : 1-5.

Yuvisa, Rohaman, H. 2008, Pengaruh Identifikasi Auditor atas Klien Terhadap Objektivitas Auditor dengan Auditor
Tenure, Client Importance dan Client Image sebagai Variabel anteseden, No : $1-31$.

www.idx.co.id

\section{LAMPIRAN}

Lampiran 1

Hasil Uji Statistik Deskriptif

Descriptive Statistics

\begin{tabular}{|l|r|r|r|r|r|}
\hline & \multicolumn{1}{|c|}{$\mathrm{N}$} & \multicolumn{1}{c|}{ Minimum } & Maximum & \multicolumn{1}{c|}{ Mean } & Std. Deviation \\
\hline GCO & 138 & .00 & 1.00 & .1594 & .36740 \\
AT & 138 & 1.00 & 5.00 & 2.1304 & 1.05903 \\
DD & 138 & .00 & 1.00 & .1449 & .35331 \\
KA & 138 & .00 & 1.00 & .1812 & .38655 \\
LASTOPN & 138 & .00 & 1.00 & .1377 & .34582 \\
Valid N (listwise) & 138 & & & & \\
\hline
\end{tabular}


Lampiran 2

Hasil Uji Kesamaan Koefisien

\begin{tabular}{|c|c|c|c|c|c|c|}
\hline \multicolumn{7}{|c|}{ Coefficients $^{a}$} \\
\hline \multirow{2}{*}{\multicolumn{2}{|c|}{ Model }} & \multicolumn{2}{|c|}{ Unstandardized Coefficients } & Standardized & $\mathrm{t}$ & Sig. \\
\hline & & $B$ & Std. Error & Beta & & \\
\hline & DT1 & .440 & .392 & .448 & 1.123 & .264 \\
\hline & DT2 & .057 & .367 & .059 & .157 & .876 \\
\hline & DT3 & .064 & .374 & .065 & .171 & .865 \\
\hline & DT4 & .070 & .382 & .071 & .182 & .856 \\
\hline & DT5 & -.015 & .387 & -.015 & -.038 & .970 \\
\hline & AT_DT1 & -.180 & .201 & -.368 & -.896 & .372 \\
\hline & AT_DT2 & -.053 & .191 & -.120 & -.278 & .782 \\
\hline & AT_DT3 & -.041 & .189 & -.127 & -.217 & .829 \\
\hline & AT_DT4 & -.070 & .191 & -.205 & -.365 & .716 \\
\hline & AT_DT5 & $-7.040 E-014$ & .197 & .000 & .000 & 1.000 \\
\hline & DD_DT1 & -.135 & .263 & -.062 & -.514 & .609 \\
\hline & DD_DT2 & .445 & .251 & .204 & 1.771 & .079 \\
\hline & DD_DT3 & .012 & .253 & .006 & .047 & .962 \\
\hline & DD_DT4 & .047 & .271 & .019 & .172 & .864 \\
\hline & DD_DT5 & .097 & .295 & .039 & .330 & .742 \\
\hline & KA_DT1 & -.168 & .199 & -.086 & -.846 & .399 \\
\hline & KA_DT2 & -.059 & .203 & -.027 & -.291 & .772 \\
\hline & KA_DT3 & -.031 & .205 & -.014 & -.151 & .881 \\
\hline & KA_DT4 & .070 & .196 & .032 & .357 & .722 \\
\hline & KA_DT5 & .015 & .195 & .007 & .076 & .940 \\
\hline & LASTOPN_DT1 & -.016 & .323 & -.006 & -.049 & .961 \\
\hline & LASTOPN_DT2 & -.522 & .315 & -.208 & -1.654 & .101 \\
\hline & LASTOPN_DT3 & -.536 & .312 & -.246 & -1.720 & .088 \\
\hline & LASTOPN_DT4 & -.023 & .308 & -.011 & -.076 & .940 \\
\hline & LASTOPN_DT5 & -.112 & .331 & -.045 & -.338 & .736 \\
\hline
\end{tabular}

a. Dependent Variable: GCO 
Lampiran 3

Menilai Keseluruhan Model (Overall Model Fit)

\begin{tabular}{|c|c|}
\hline Iteration & -2 Log likelihood \\
\hline 1 & 122.866 \\
\hline 20 & 60.088 \\
\hline
\end{tabular}

Lampiran 4

Hasil Uji Koefisien Determinasi

\begin{tabular}{|l|r|r|r|}
\hline Step & -2 Log likelihood & $\begin{array}{c}\text { Cox \& Snell R } \\
\text { Square }\end{array}$ & $\begin{array}{l}\text { Nagelkerke R } \\
\text { Square }\end{array}$ \\
\hline 1 & $60.088^{\mathrm{a}}$ & .357 & .612 \\
\hline
\end{tabular}

a. Estimation terminated at iteration number 20 because maximum iterations has been reached. Final solution cannot be found.

Lampiran 5

Kelayakan Model Regresi

\begin{tabular}{|l|c|}
\hline Step & Sig. \\
\hline 1 & .934 \\
\hline
\end{tabular}

Lampiran 6

Matriks Klasifikasi

\begin{tabular}{|c|c|c|c|}
\hline \multirow[t]{3}{*}{ Observed } & \multicolumn{3}{|c|}{ Predicted } \\
\hline & \multicolumn{2}{|c|}{ GCO } & \multirow{2}{*}{$\begin{array}{c}\text { Percentage } \\
\text { Correct }\end{array}$} \\
\hline & $\mathbf{0}$ & 1 & \\
\hline GCO 0 & 113 & 3 & 97.4 \\
\hline 1 & 6 & 16 & 72.7 \\
\hline $\begin{array}{l}\text { Overall } \\
\text { Percentage }\end{array}$ & & & 93.5 \\
\hline
\end{tabular}




\section{Lampiran 7}

\section{Hasil Uji Koefisien Regresi Logistik}

Variables in the Equation

\begin{tabular}{|c|c|c|c|c|c|c|c|}
\hline & & $B$ & S.E. & Wald & $d f$ & Sig. & $\operatorname{Exp}(B)$ \\
\hline \multirow{5}{*}{ Step $1^{a}$} & AT & .129 & .354 & .133 & 1 & .715 & 1.138 \\
\hline & DD & .968 & .888 & 1.187 & 1 & .276 & 2.633 \\
\hline & $\mathrm{KA}$ & -18.563 & 7965.582 & .000 & 1 & .998 & .000 \\
\hline & LASTOPN & 4.056 & .788 & 26.476 & 1 & .000 & 57.756 \\
\hline & Constant & -3.081 & .923 & 11.136 & 1 & .001 & .046 \\
\hline
\end{tabular}

a. Variable(s) entered on step 1: AT, DD, KA, LASTOPN. 